ISSN 1517-7076 editorial, 2013

\title{
Editorial
}

\section{Materiais para uso na indústria de energia}

A indústria convencional, que gera, transmite e distribui energia para uso da nossa sociedade estabeleceu uma ampla gama de materiais que garantem o sucesso dessa empreitada. O beneficiamento do petróleo e uso do gás natural e dos seus derivados, por exemplo, requereu um grande aprimoramento dos aços usados na produção de combustível, quanto às resistências à corrosão e à fragilização pelo hidrogênio e de materiais compósitos para dutos flexíveis. Para as refinarias, foram desenvolvidos aços e revestimentos especiais para trabalhos em altas temperaturas e uma plêiade de catalisadores. Ao mesmo tempo em que a indústria de óleo e gás segue seu curso crescente de atividades geradoras de novos materiais, abre espaço também crescente para materiais especiais usados pelas empresas que produzem energia a partir de fontes renováveis. Muita inovação tem sido apresentada em materiais para turbinas de usinas hidrelétricas, para componentes de geradores eólicos e para uso em células fotovoltaicas de última geração. Mas, essas são modalidades de energias fósseis e renováveis em largo uso atual e, por isso, mais bem conhecidas. Vale a pena direcionar a atenção das comunidades científica e empresarial para a grande atividade criativa que trabalha no desenvolvimento de materiais para a energia do hidrogênio. Neste caso, por exemplo, são necessários recipientes para o armazenamento de hidrogênio gasoso sob altas pressões, de cerca de 700 bar. Polímeros de alta densidade e materiais compósitos a base fibras de carbono devem garantir a resistência mecânica requerida e também estanqueidade a gás. As pilhas a combustível de óxido sólido trabalham em altas temperaturas, acima de $650^{\circ} \mathrm{C}$, e têm o desafio de garantir a compatibilidade mecânica entre materiais metálicos e cerâmicos em ambientes oxidantes e redutores. Particularmente, um grande desenvolvimento ocorre em materiais cerâmicos com estrutura da perovskita, apresentando propriedades eletrocatalíticas especiais. Isso inclui a capacidade de promover no anodo a oxidação direta do hidrogênio e até de combustíveis mais complexos como o biometano e o etanol, para possibilitar a sua utilização direta, sem reforma prévia. E, além disso, também a habilidade de promover a redução eficiente do oxigênio no catodo, com uma perovskita apropriada. O Corpo Editorial da revista Matéria ficará contente em trabalhar esses temas através de artigo de sua autoria submetido para publicação. Não hesite!

Cordialmente,

Paulo Emílio V. de Miranda

Editor-Chefe

Revista Matéria 